\title{
ASSESSMENT OF ANTIOXIDANT PROPERTIES OF DIFFERENT FOMES FOMENTARIUS EXTRACTS
}

\author{
LORETA-ANDREA BOJIN ${ }^{1 \#}$, ALINA-FLORINA SERB ${ }^{1 \#}$, MIHAI-COSMIN PASCARIU ${ }^{2,3 \#,}$ \\ ALINA MOACA ${ }^{4}$, ROXANA KOSTICI ${ }^{5}$, VICTOR LORIN PURCĂREA ${ }^{6}$, MIRCEA PENESCU $^{6}$, \\ MIHAELA VIVIANA IVAN ${ }^{1}$, MARIUS GEORGESCU $^{1 *}$, EUGEN SISU $^{1}$ \\ 1 "Victor Babeş" University of Medicine and Pharmacy Timişoara, Faculty of Medicine, 2 Eftimie Murgu Square, 300041, \\ Timişoara, Romania \\ 2 "Vasile Goldis” Western University of Arad, Faculty of Pharmacy, 86 Liviu Rebreanu Street, 310414, Arad, Romania \\ ${ }^{3}$ Institute of Research \& Development for Electrochemistry and Condensed Matter, 300569 Timișoara, Romania \\ 4 "Victor Babes" University of Medicine and Pharmacy, Faculty of Pharmacy, Department of Toxicology, 2 Eftimie Murgu \\ Square, 300041 Timisoara, Romania \\ ${ }^{5}$ University of Medicine and Pharmacy Craiova, Faculty of Pharmacy, 2 Petru Rareș Street, 200349, Craiova, Romania \\ 6 "Carol Davila” University of Medicine and Pharmacy, 37 Dionisie Lupu Street, 020021, Bucharest, Romania
}

*corresponding author: georgescu.marius@umft.ro

${ }^{\#}$ Authors with equal contribution.

Manuscript received: October 2019

\begin{abstract}
Ten extracts of the wild, inedible mushroom Fomes fomentarius obtained with different solvents: water, $80 \%$ ethanol, absolute ethanol, acetone, methanol, petroleum ether, cyclohexane, hexane, toluene and dichlormethane, were evaluated for their free radical scavenging capacity by DPPH (2.2-diphenyl-1-picryl-hydrazyl-hydrate) assay. Methanol and ethanol extracts showed the highest antioxidant activity (AOA) independent of the concentration of DPPH ethanolic solution which was used, while aqueous and petroleum ether extracts have provided increased AOAs only when the DPPH ethanolic solution concentration was decreased. Thus, the present results show that this wild inedible mushroom has good potential as a source of natural antioxidants to be used in food industry, medicine and dermatocosmetics.
\end{abstract}

\section{Rezumat}

Zece extracte de ciuperci sălbatice, necomestibile Fomes fomentarius, în solvenți cu diferite polarități: apă, etanol $80 \%$, etanol absolut, acetonă, metanol, eter de petrol, ciclohexan, hexan, toluen și diclormetan, au fost evaluate privind capacitatea lor de eliminare a radicalilor liberi prin metoda DPPH (2, 2-difenil-1-picril-hidrazil-hidrat). Extractele obținute cu metanol și etanol au arătat cea mai mare activitate antioxidantă (AOA) independent de concentrația soluției etanolice de DPPH utilizate, în timp ce extractele apoase și cele obținute cu eter de petrol au furnizat activități antioxidante crescute doar atunci când concentrația de soluție etanolică de DPPH a fost redusă. Astfel, rezultatele prezente au arătat că această ciupercă sălbatică necomestibilă are un potențial bun ca sursă de antioxidanți naturali pentru a fi utilizată în industria alimentară, în medicină și în domeniul dermatocosmeticelor.

Keywords: Fomes fomentarius, antioxidant activity (AOA), DPPH, mushroom extract

\section{Introduction}

Oxidative stress represents a lack of balance between the production of reactive species of oxygen (ROS) and nitrogen (RNS) and the antioxidant defence mechanisms of the body. ROS production can be in vivo due to normal biological processes (cellular metabolism) while in the external environment the principal sources of ROS are smoking, xenobiotics, ionizing and ultraviolet radiation, ultrasonics, different pollutants and allergens [36]. The overproduction of ROS and RNS has been linked to several pathologies such as diabetes, obesity, AIDS, rheumatoid arthritis, chronic glomerulonephritis, ulcerative colitis, hepatitis, adult respiratory distress syndrome (ARDS), neurodegenerative diseases (Alzheimer, Parkinson), multiple sclerosis, muscular dystrophy, cataract, male infertility, certain types of cancer and cardiovascular diseases (atherosclerosis and myocardial infarction) [36]. The aerobic cells have developed antioxidant defence mechanisms to supress the damaging effects of ROS. Antioxidants can be divided according to their nature and action into enzymatic antioxidants (superoxide dismutase, catalase, glutathione peroxidase, glutathione reductase, heme oxygenase) and non-enzymatic antioxidants, originating from nutrition (carotenoids, $\alpha$ tocopherol, ascorbic acid, coenzyme $\mathrm{Q}_{10}$, catechins, proanthocyanidins, quercetin, hesperidin, curcuminoids, ellagic acid, lycopene, lutein and zeaxanthin, $\alpha$-lipoic acid, selenium, zinc, copper, manganese, etc.) or various metabolic processes (glutathione, ceruloplasmin, albumin, 
FARMACIA, 2020, Vol. 68, 2

bilirubin, transferrin, ferritin, uric acid, haptoglobin, melatonin) [36]. Numerous protective antioxidant nutrients are usable as dietary supplements, while antioxidant-containing foods can protect food quality by preventing oxidative deterioration. The recently arisen restriction on the use of synthetic antioxidants, such as butylated hydroxytoluene (BHT), butylated hydroxyanisole (BHA) and others has provoked a surge of interest towards naturally obtained antioxidant substances [4, 26, 29]. Of these natural sources of antioxidants, mushrooms have drawn increasingly more attention as a commercial source of antioxidants [6, 12-14]. It was shown that the antioxidant compounds found in fruit bodies, mycelium and broth of various mushrooms are: polyphenols, including flavonoids, glycosides, polysaccharides, tocopherols, ergothioneine, carotenoids, and ascorbic acid [3, 7, 11, 15, 22, 28, 33, 40]. These compounds can demonstrate their protective properties at different stages of the oxidation process and by different mechanisms $[3,6,7,11-15,22,28$, 33, 40].

Mushrooms have attracted considerable attention not just because of their antioxidant properties, but also because of numerous other important bioactivities antidiabetic, antitumor, anticoagulant, anti-inflammatory, antibacterial, antiallergic, antifungal, antiviral, hypolipidemic, antiatherogenic, hepatoprotective, immunological activities, making them suited for a wide range of uses [8, 13, 20, 21].

Edible as well as inedible mushroom species, such as the ones belonging to the Polyporaceae, Scutigeraceae, Xylariaceae, Thelephoraceae and Paxillaceae families, have been used to source for bioactive molecules of multiple applications [30, 32].

One of the polypore family, Fomes fomentarius (tinder fungus is a large, inedible, white, woody fungus, which develops as a parasite on beech and other foliated species. It was used to relieve pain, treat rheumatism, dysmenorrhoea, haemorrhoids, bladder disorders, oesophageal, gastric and uterine cancers [9]. Some studies have shown that Fomes fomentarius contains substances that exhibit strong antiviral activity against the human immunodeficiency virus HIV-1, and antimicrobial properties against Candida albicans and Helicobacter pylori [37] and of several other pathogenic bacteria [1, 16, 34]. In addition, compounds with potential antitumour, immunomodulatory and antiinflammatory activity were also identified in Fomes fomentarius [9, 37, 39]. Unlike other species, Fomes fomentarius did not constitute the subject of detailed research of its chemical and biological activities. However, considering its traditional use and what previous studies exist, it could represent a valuable source of bioactive compounds. Most literature data concerning antioxidant properties of Fomes fomentarius covers only a limited number of solvents used for extraction (methanol, ethanol and water). Thus, we tested the antioxidant activity (AOA) of different
Fomes fomentarius extracts obtained by using ten different solvents in order to find the optimal ones that could provide the highest AOA. To our knowledge, the present study is the first one which reports on the use of such a large scale of solvent polarities in order to obtain extracts of this wild inedible mushroom and to evaluate its AOA.

\section{Materials and Methods}

\section{Chemicals}

All reagents used to obtain Fomes fomentarius extracts were of analytical grade and were purchased from various suppliers: petroleum ether, dichlormethane and acetone from S.C. ChimReactiv SRL, Romania (Batch No: 649-328-00-1, 602-004-00-3, 606-001-00-8), hexane, cyclohexane, toluene and methanol from Merck KGaA, Germany (Batch No: 601-037-00-0, 601-017-00-1, 205-625-8, 603-001-00-X) and ethanol absolute from Chimopor S.A. (Batch No 200-578-6), $80 \%$ ethanol, and ultrapure water.

To evaluate the antioxidant activity (AOA) the following reagents were used: 2.2-diphenyl-1-picrylhydrazyl (DPPH) (Batch No: \# STBF5255V) acquired from Sigma-Aldrich, Germany, 96\% ethanol, purchased from S.C. Chemical Company SA, Romania and ascorbic acid, acquired from Lach-Ner Company, Czech Republic. Fungal material

Samples of wild-growing species of Fomes fomentarius were collected from Vâlcea forest (Romania) in October 2015 and were deposited in the research section of the Biochemistry Department of the "Victor Babeş" University of Medicine and Pharmacy of Timişoara, Romania. The Fomes fomentarius species was identified according to the Moser criteria [23].

\section{Obtaining Fomes fomentarius extracts}

A few samples of the collected Fomes fomentarius mushroom were washed, cut into small pieces, ground down manually and stored for extraction at $-28^{\circ} \mathrm{C}$. Aliquots of approximately 15 grams of fresh mushroom were further used for each extraction procedure using $150 \mathrm{~mL}$ of ten different solvents (Table I) in Erlenmeyer flasks and left on a magnetic stirrer at room temperature for 24 hours at $25^{\circ} \mathrm{C}$. After 24 hours the extracts were filtered and evaporated at $40^{\circ} \mathrm{C}$ to dryness using a Buchi rotavapor. Extraction yields were calculated for each sample. The aqueous extract contained the highest mass of dry material $(0.435 \mathrm{~g})$ followed by the ethanol $80 \%$ extract $(0.347 \mathrm{~g})$, while the petroleum ether extract contained the lowest mass of dry material $(0.060 \mathrm{~g})$. The mushroom dry extracts were kept at $-25^{\circ} \mathrm{C}$ until further use. For preparing stock solutions $(5 \mathrm{mg} / \mathrm{mL})$ crude extracts were re-dissolved in the corresponding solvent and used for in vitro measurement of the AOA with the solvents presented in Table I. 
FARMACIA, 2020, Vol. 68, 2

Table I

Solvents used for obtaining the Fomes fomentarius

extracts

\begin{tabular}{|c|c|c|}
\hline No. & Solvent type & Solvent annotation \\
\hline 1 & Ultrapure water & S1 \\
\hline 2 & Ethanol $80 \%$ & S2 \\
\hline 3 & Ethanol absolute & S3 \\
\hline 4 & Acetone & S4 \\
\hline 5 & Methanol & S5 \\
\hline 6 & Petroleum ether & S6 \\
\hline 7 & Cyclohexane & S7 \\
\hline 8 & Hexane & S8 \\
\hline 9 & Toluene & S 9 \\
\hline 10 & Dichlormethane & S10 \\
\hline
\end{tabular}

Determination of in vitro AOA

AOA was evaluated by using DPPH (2,2-diphenyl-1picrylhydrazyl) assay. DPPH is a free-radical used to evaluate the antioxidant potential of different extracts. For this purpose, two ethanolic solutions of DPPH $1 \mathrm{mM}$ and $0.1 \mathrm{mM}$ were prepared, by weighing $19.7 \mathrm{mg}$ (for $1 \mathrm{mM}$ solution) and $1.97 \mathrm{mg}$ (for $0.1 \mathrm{mM}$ solution) of DPPH respectively and dissolving them in $50 \mathrm{~mL}$ $96 \%$ ethanol. The two ethanolic solutions were kept at $4{ }^{\circ} \mathrm{C}$ in darkness until use.

Starting from the original method of Ramadan et al. [31], Moacă et al. [24] optimized the AOA technique, by measuring $0.5 \mathrm{~mL}$ of each extract, mixing it with $2 \mathrm{~mL}$ of solvent (the same solvent used for the extraction procedure for each sample extract) and with $0.5 \mathrm{~mL}$ ethanol solution of DPPH $1 \mathrm{mM}$ and $0.1 \mathrm{mM}$ respectively. The absorbances of the extracts were measured for 10 minutes continuously, every
5 seconds, using a UV-Line 9400 Spectrophotometer (from SI Analytics) at $516 \mathrm{~nm}$. In parallel, an ethanolic solution of ascorbic acid $2 \mathrm{mM}$ was prepared, which was used as positive control and analysed under the same conditions.

The percentage of antioxidant activity (\% AOA) of each extract was calculated using the formula described below:

$$
A O A[\%]=100-\left(A_{\text {extract }} / A_{D P P H}\right) \cdot 100
$$

where: AOA - the antioxidant activity percent; $\mathrm{A}_{\text {extract }}$ - the absorbance of the mushroom extract, measured at $516 \mathrm{~nm}$; $A_{\mathrm{DPPH}}$ - the absorbance of the DPPD free radical, without extract, measured at $516 \mathrm{~nm}$.

Moreover, the UV-VIS spectra of all the ten mushroom extracts were obtained and the maximum absorbances were compared.

\section{Results and Discussion}

Figure 1 depicts the antioxidant activities (AOAs) of the ten mushroom extracts (S1-S10) compared to the AOA of the ascorbic acid ethanolic solution which was used as control, when an ethanolic DPPH solution of $1 \mathrm{mM}$ was used. In order to evaluate AOAs of these extracts, a stock solution of $5 \mathrm{mg} / \mathrm{mL}$ was prepared from each of them. The positive control (ethanolic solution of ascorbic acid) was also evaluated for 10 minutes with DPPH $1 \mathrm{mM}$ ethanolic solution. By recording the absorbances continuously, it was possible to make a precise determination of the time and the speed at which the DPPH free radical is consumed by the antioxidants present in the mushroom extracts.

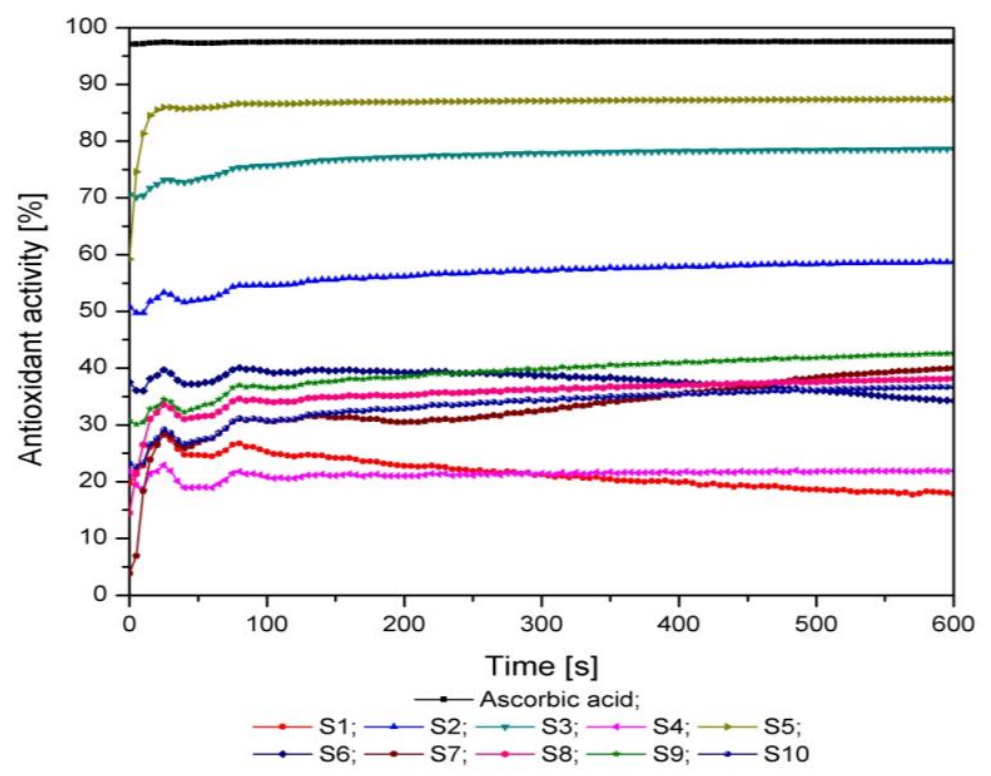

Figure 1.

The time-dependent AOAs of ten mushroom extracts, using $1 \mathrm{mM}$ DPPH ethanolic solution

As can be seen in Figure 1 all the Fomes fomentarius extracts present antioxidant activity compared with the antioxidant activity of the ascorbic acid ethanolic solution. The highest AOA was obtained in the case of samples: S5 (MeOH extract), S3 (EtOH absolute extract) and S2 (80\% EtOH extract). For other extracts, 
the antioxidant activity percentage was in the range of $10-40 \%$. Moreover, these extracts displayed fluctuations regarding AOA, namely they reacted faster with DPPH in the first 100 seconds. This phenomenon probably occurs due to the relatively low amounts of antioxidant compounds present in the samples. The kinetics of the reaction are pretty much the same for all extracts, which means that there are no differences regarding the percentage of inhibition of the sample, irrespective of the solvent used at extraction. In almost all extracts, after 350 seconds the free radical is totally consumed by the antioxidants contained in each sample and after this time the kinetics of the reaction reached equilibrium.

In the case of the mushroom extracts: S7 (cyclohexane extract), S9 (toluene extract) and S10 (dichloromethane extract), the equilibrium had not been reached even after 20 minutes (data not shown). Regarding samples $\mathrm{S} 1\left(\mathrm{H}_{2} \mathrm{O}\right.$ extract) and $\mathrm{S} 6$ (petroleum ether extract), after the DPPD radical was consumed, it was observed that the absorbances of the samples increased, leading to a decrease of the percentage of antioxidant activity, as compared to other samples when other solvents were used. As shown in literature, this could occur due to the fact that not many compounds are extracted in $\mathrm{H}_{2} \mathrm{O}$, and it seem that in petroleum ether as well. Table II displays the inhibition percentage, relative to the concentration of $5 \mathrm{mg} / \mathrm{mL}$ of all the ten mushroom extracts and the inhibition percent of ascorbic acid ethanolic solution, respectively, determined with DPPH ethanolic solution $1 \mathrm{mM}$. The inhibition percentage was calculated with the equation presented above.

Table II

Composition and codification of metronidazole gel formulations

\begin{tabular}{|c|c|c|c|}
\hline \multirow[t]{12}{*}{1} & \multicolumn{3}{|c|}{ Mushroom extracts } \\
\hline & Sample & Concentration [mg/mL] & $\%$ inhibition \\
\hline & $\mathrm{S} 1\left(\mathrm{H}_{2} \mathrm{O}\right.$ extract $)$ & & $15.85 \pm 0.024$ \\
\hline & $\mathrm{S} 2$ (EtOH $80 \%$ extract) & & $59.65 \pm 0.009$ \\
\hline & S3 (EtOH absolute extract) & & $78.93 \pm 0.006$ \\
\hline & S4 (acetone extract) & & $22.05 \pm 0.038$ \\
\hline & S5 (MeOH extract) & 5 & $87.47 \pm 0.004$ \\
\hline & S6 (petroleum ether extract) & & $35.89 \pm 0.067$ \\
\hline & S7 (cyclohexane extract) & & $44.02 \pm 0.079$ \\
\hline & S8 (hexane extract) & & $39.49 \pm 0.009$ \\
\hline & S9 (toluene extract) & & $44.57 \pm 0.051$ \\
\hline & S10 (dichloromethane extract) & & $37.73 \pm 0.024$ \\
\hline 2 & Ascorbic acid & $0.4 \mathrm{mg} / \mathrm{mL}$ & $97.57 \pm 0.017$ \\
\hline
\end{tabular}

The results are expressed as average \pm SD $(n=3)$

Figure 2 present the time-dependent AOAs of the same mushroom extracts, but using a ten-fold lower concentration of the free radical (DPPH - $0.1 \mathrm{mM}$ ). All the mushroom extracts show AOA in this case as well, which was compared with ascorbic acid AOA as the positive control, due to having the highest AOA value (95\%).

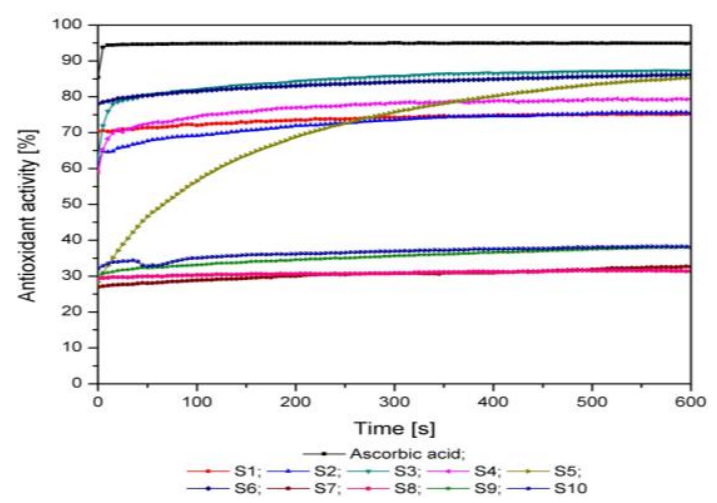

Figure 2.

The time-dependent AOAs of ten mushroom extracts, using $0.1 \mathrm{mM}$ DPPH ethanolic solution

When the $0.1 \mathrm{mM}$ DPPH free radical was used, the highest antioxidant activity percentage were obtained in the case of sample S3 (absolute EtOH extract), S6 (petroleum ether extract) and S5 (MeOH extract). When methanol was used to extract active compounds from Fomes fomentarius, this extract (S5) reacted slowly with DPPH throughout the recording time of the analysis, equilibrium being reached after $1000 \mathrm{~s}(\sim 17$ minutes, data not shown). The following samples showed high AOA: S4 (acetone extract); S2 (80\% EtOH extract) and $\mathrm{S} 1\left(\mathrm{H}_{2} \mathrm{O}\right.$ extract). The high percentage of AOAs in the case of $\mathrm{H}_{2} \mathrm{O}$, acetone and petroleum ether extracts was in the highest likelihood due to the low content of free radical $(0.1 \mathrm{mM})$ used to scavenge the substrate.

In the case of the other extracts, the free radical was consumed in the first 250 seconds, and afterwards the kinetics of the reaction reached equilibrium.

In the case of sample S10 (dichloromethane extract), a fluctuation of the AOA could be observed in the first 100 seconds; this may be due to the small amount of active compounds present in the extract.

Table III also shows the inhibition percentage relative to the concentration of $5 \mathrm{mg} / \mathrm{mL}$ of all the ten mushroom extracts and the inhibition percentage of ascorbic acid ethanolic solution determined with DPPH ethanolic solution $0.1 \mathrm{mM}$, respectively. The inhibition percentage was calculated using the same equation presented 
FARMACIA, 2020, Vol. 68, 2

previously. All the extracts present an antioxidant activity percentage slightly lower at the beginning of the reaction (the initial moment) compared to the end of the reaction, after 1200 seconds (the final moment - data not shown).

Table III

The inhibition percentage induced by ethanol solutions of ascorbic acid as compared to mushrooms extracts

\begin{tabular}{|c|c|c|c|}
\hline 1 & \multicolumn{3}{|c|}{ Mushroom extracts } \\
\hline & Sample & Concentration [mg/mL] & \% inhibition \\
\hline & $\mathrm{S} 1\left(\mathrm{H}_{2} \mathrm{O}\right.$ extract $)$ & \multirow{10}{*}{5} & $75.70 \pm 0.010$ \\
\hline & S2 (80\% EtOH extract) & & $76.88 \pm 0.009$ \\
\hline & S3 (absolute EtOH extract) & & $87.72 \pm 0.005$ \\
\hline & S4 (acetone extract) & & $80.55 \pm 0.052$ \\
\hline & S5 (MeOH extract) & & $88.87 \pm 0.045$ \\
\hline & S6 (petroleum ether extract) & & $88.74 \pm 0.052$ \\
\hline & S7 (cyclohexane extract) & & $35.53 \pm 0.052$ \\
\hline & S8 (hexane extract) & & $32.04 \pm 0.052$ \\
\hline & S9 (toluene extract) & & $41.07 \pm 0.052$ \\
\hline & S10 (dichloromethane extract) & & $39.74 \pm 0.016$ \\
\hline 2 & Ascorbic acid & $0.4 \mathrm{mg} / \mathrm{mL}$ & $94.82 \pm 0.052$ \\
\hline
\end{tabular}

The results are expressed as average \pm SD $(n=3)$

Our results regarding AOA as inhibition percentage when the $\mathrm{MeOH}$ mushroom extract was tested were comparable to the results of other authors $[5,16,17$, 25] when AOA was expressed as inhibition percentage and $\mathrm{EC}_{50}$ value, revealing a high antioxidant potential. This high value of AOA could be explained by a rich content of polyphenols in the $\mathrm{MeOH}$ mushroom extract [17]. For ethanolic extracts our data were in accordance with the results obtained by Karaman et al. [17] and Nowacka et al. [27] while Kalyoncu et al. [18] showed a decreased AOA (\%). Some authors showed that hydro distilled extracts of Fomes fomentarius are the most active towards DPPH radical, compared with other solvents (ethanol - low AOA and chloroformno AOA) [18]. Moreover, other authors [10] obtained considerable AOA for Fomes fomentarius harvested in Serbia hydrodistilled extracts $\left(\mathrm{EC}_{50}-1.31 \mu \mathrm{g} / \mathrm{mL}\right)$, even higher than vitamin $\mathrm{C}\left(\mathrm{EC}_{50}-4.22 \mu \mathrm{g} / \mathrm{mL}\right)$ [19]. This increased AOA may be partially explained by translocation of a great amount of polyphenols (157 \pm 8 $\mathrm{mg} \mathrm{GAE} / \mathrm{g}$ ) stored in the spores, as a result of hydrodistillation which destroys sporoderm [33]. On the contrary, the aqueous extracts (obtained at $100^{\circ} \mathrm{C}$ ) of Fomes fomentarius harvested in Iran showed a decrease of almost 70 times of the AOA presented as $\mathrm{EC}_{50}$ [38]. In our case the water extract had the lowest AOA (15.85\%) when DPPH ethanolic solution of $1 \mathrm{mM}$ was used and the antioxidant potential increased substantially by decreasing the concentration of DPPH solution 10 fold. It can be considered that the various differences in AOA exhibited by Fomes fomentarius extracts are also likely to be related to the places of harvesting and the climatic conditions, as well as the time elapsed from harvesting to analysis.

The UV-VIS spectrum of all ten mushroom extracts is shown in Figure 3. Table IV presents the maximum absorbance of each mushroom extracts as a function of wavelength. S1 ( $\mathrm{H}_{2} \mathrm{O}$ extract), S3 (absolute EtOH extract), S5 (MeOH extract) and S6 (petroleum ether extract) samples present values of absorbance that exceed the registration range and have therefore been diluted to fit the scale (Figure 3). Only the final obtained data is presented in Figure 3.

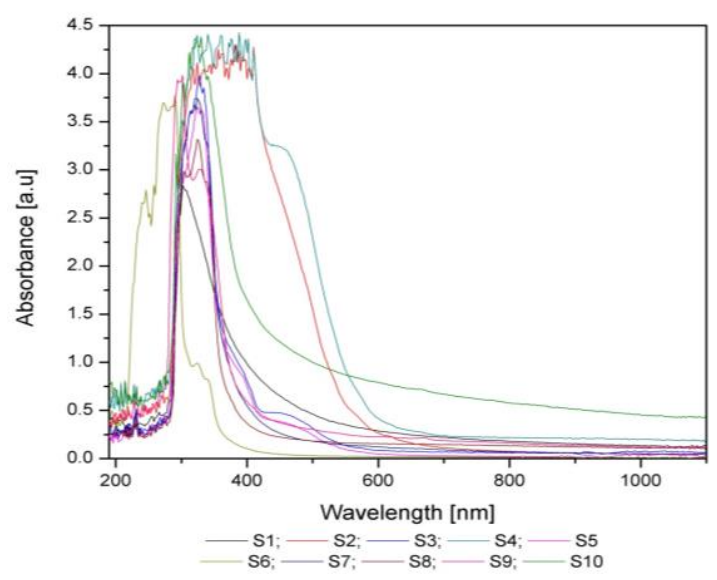

Figure 3.

UV-VIS spectra of the mushroom extracts. S1 and S3 samples were diluted 1:3, while for S5 and S6 the dilution was 1:5

All solutions have maximum absorbances in the range of $300-400 \mathrm{~nm}$, except for the S6 extract. The recording of the UV spectra and the presentation of the absorbances at the wavelength of maximum absorption, offers a quantitative benchmark for other experiments that wish to reproduce the data regarding the antioxidant property of the extracted compounds. A number of compounds (for which there were standards) were identified in extracts S1-S8 (caffeic acid, protocatechuic acid, p-coumaric, and ferulic acids) by combining chromatographic (TLC or HPTLC) with spectrophotometric (IR or UV-VIS) methods [2, 5, 14, 35 ] and the identification of other compounds will continue through derivatization experiments and analysis by ESI-MS or MALDI-TOF-MS. 
Table IV

Maximum absorbance of the extracts as a function of wavelength

\begin{tabular}{ccc} 
& Maximum absorbance of the extracts as a func \\
\hline Sample & Maximum absorbance & Wavelength [nm] \\
\hline S1 ( $\mathrm{H}_{2}$ O extract) & 2.839 & 302 \\
S2 (EtOH 80\% extract) & 4.301 & 382 \\
S3 (EtOH absolute extract) & 3.971 & 328 \\
S4 (acetone extract) & 4.428 & 388 \\
S5 (MeOH extract) & 3.651 & 324 \\
S6 (petroleum ether extract) & 3.769 & 290 \\
S7 (cyclohexane extract) & 3.746 & 324 \\
S8 (hexane extract) & 3.316 & 324 \\
S9 (toluene extract) & 3.983 & 302 \\
S10 (dichloromethane extract) & 4.383 & 330 \\
\hline
\end{tabular}

\section{Conclusions}

The data obtained shows that Fomes fomentarius, while being a wild inedible mushroom, could represent a viable source of bioactive compounds with antioxidant potential. The present study is the first to use a large set of different solvents for Fomes fomentarius extraction and evaluation of the antioxidant properties of the obtained extracts. The highest AOAs were obtained for the $\mathrm{MeOH}$ and $\mathrm{EtOH}$ absolute extracts, independent of the concentration of the DPPH ethanolic solution. Moreover, when water and petroleum ether were used as solvents for extraction, increased AOAs were also recorded, but only when the concentration of the DPPH ethanolic solution was decreased. The maximum absorbances obtained in the UV-VIS spectrum for each of the ten mushroom extracts could be attributed to different compounds, most of them polyphenols with antioxidant properties, but further studies are necessary to precisely identify these components and to determine which of them is more effective in ROS scavenging. The demonstrated antioxidant potentials of mushrooms can be useful in the pharmaceutical and food industry, by decreasing the use of synthetic compounds, and might offer health benefits by improving the antioxidative defence mechanisms and by diminishing the risk of various pathologies.

\section{Acknowledgement}

This work was supported by the Romanian National Authority for Scientific Research (CNCS-UEFISCDI) through project PN-II-PCCA-2011-142. Part of research was done at the Centre of Genomic Medicine from the "Victor Babeş" University of Medicine and Pharmacy of Timișoara, Romania, POSCCE 185/48749, contract 677/09.04.2015.

\section{Conflict of interest}

The authors declare no conflict of interest.

\section{References}

1. Bandas C, Orha C, Misca C, Lazau C, Sfirloaga P, Olariu S, Photocatalytical inactivation of Enterococcus faecalis from water using functional materials based on natural zeolite and titanium dioxide. Chin J Chem Eng., 2014; 22(1): 38-43.

2. Chahdoura H, Barreira JCM, Barros L, SantosBuelga C, Ferreira ICFR, Achour L, Phytochemical characterization and antioxidant activity of Opuntia microdasys (Lehm.) Pfeiff flowers in different stages of maturity. J Funct Foods, 2014; 9(1): 27-37.

3. Chen SY, Ho KJ, Hsieh YJ, Wang LT, Mau JL, Contents of lovastatin, $\gamma$ aminobutyric acid and ergothioneine in mushroom fruiting bodies and mycelia. LWT Food Sci Technol., 2012; 47: 274-278.

4. Dărăban A, Olah NK, Burtescu RF, Pripon Furtună F, Hanganu D, Simon I, Bojiţă M, Hegheş CS, Filip L, The evaluation of antioxidant capacity of propolis originating from Western Romania. Farmacia, 2019; 67(1): 111-116.

5. Dundar A, Okumus V, Ozdemir S, Serdar Celik K, Boğa M, Ozcagli E, Determination of cytotoxic, anticholinesterase, antioxidant and antimicrobial activities of some wild mushroom species. Cogent Food \& Agric., 2016; 2: 1-10.

6. Ferreira ICFR, Barros L, Abreu RMV, Antioxidants in wild mushrooms. Curr Med Chem., 2009; 16: 1543-1560.

7. Ferreira IC, Heleno SA, Reis FS, Stojkovic D, Queiroz MJ, Vasconcelos MH, Sokovic M, Chemical features of Ganoderma polysaccharides with antioxidant, antitumor and antimicrobial activities. Phytochemistry, 2015; 114: 38-55.

8. Ferreira ICFR, Vaz JA, Vasconcelos MH, Martins A, Compounds from wild mushrooms with antitumor potential. Anti-cancer Agents Med Chem., 2010; 10: 424-436.

9. Grienke U, Zöll M, Peintner U, Rollinger JM, European medicinal polypores - A modern view on traditional uses. J. Ethnopharmacol., 2014; 154(3): 564-583.

10. Glumaca M, Pejinb B, Karamana M, Mojovićc M, Matavulja M, Lignicolous fungi hydrodistilled extracts may represent a promising source of natural phenolics. Nat Prod Res., 2017; 31(1): 104-107.

11. Ioanoviciu SD, Ivan C, Matusz P, Olariu S, Lighezan $\mathrm{D}$, Morphological variability of the hepatic portal vein posterior branch: study on corrosion casts. Mater Plast., 2015; 52(2): 263-265.

12. Ivan C, Nica CC, Dobrescu A, Belic O, Matusz P, Olariu S, Using human intrahepatic bile duct system corrosion casts in training of the medical students and residents. Mater Plast., 2015; 52(1): 48-50. 
13. Khatua S, Paul S, Acharya K, Mushroom as the potential source of new generation of antioxidant: A review. Res J Pharm Technol., 2013; 6: 496-505.

14. Kozarski M, Klaus A, Jakovljevic D, Todorovic N, Vunduk J, Petrović P, Niksic M, Vrvic MM, van Griensven L, Antioxidants of edible mushrooms. Molecules, 2015; 20: 19489-19525.

15. Kozarski M, Klaus A, Vunduk J, Zizak Z, Niksic M, Jakovljevic D, Vrvic MM, van Griensven LJLD, Nutraceutical properties of the methanolic extract of edible mushroom Cantharellus cibarius (Fries): Primary mechanisms. Food Funct., 2015; 6: 1875-1886.

16. Kolundzic $M$, Grozdanic ND, Dodevskac $M$, Milenkovic M, Sistoe F, Mianie A, Farronato G, Kundakovic T, Antibacterial and cytotoxic activities of wild mushroom Fomes fomentarius (L.) Fr., Polyporaceae. Ind Crops Prod., 2016; 79: 110-115.

17. Karaman M, Stahl M, Vulić J, Vesić M, CanadanovićBrunet J, Wild-growing lignicolous mushroom species as sources of novel agents with antioxidative and antibacterial potentials. Int J Food Sci Nutr., 2014; 65(3): 311-319.

18. Kalyoncu F, Oskay M, Kayalar H, Antioxidant activity of the mycelium of 21 wild mushroom species. Mycology, 2010; 1(3): 195-199.

19. Kosanic M, Rankovic B, Dasic M, Mushrooms as possible antioxidant and antimicrobial agents. Iran J Pharm Res., 2012; 11(4): 1095-1102.

20. Loria-Kohen V, Lourenco-Nogueira T, EspinosaSalinas I, Marin FR, Soler-Rivas C, Ramirez de Molina A, Nutritional and functional properties of edible mushrooms: A food with promising health claims. J Pharm Nutr Sci., 2014; 4: 187-198.

21. Lindequist U, Niedermeyer THJ, Julich WD, The Pharmacological potential of mushrooms. eCAM, 2005; 2: 285-299.

22. Matusz P, Miclăuş GD, Gabriel A, Catereniuc I, Olariu S, Tubbs RS, Loukas M, Single ectopic thoracic renal artery associated with a normal kidney position and renal artery stenosis: a case report and review of literature. Rom J Morphol Embryol., 2015; 56(2): 557-562.

23. Moser M, In keys to Agaricus and Boleti (Polyporales, Boletales, Agaricales, Russulales). Ed. Kibby, G Transl Plant, S London: Roger Phillips, 1983.

24. Moacă EA, Farcas C, Ghitu A, Coricovac D, Popovici R, Caraba-Meita NL, Ardelean F, Antal DS, Dehelean C, Avram S, A comparative study of Melissa officinalis leaves and stems ethanolic extracts in terms of antioxidant, cytotoxic, and antiproliferative potential. Evid Based Comp Alternat Med., 2018; 2018: 1-12.

25. Mircea $C$, Cioancă $O$, Iancu $C$, Tătărîngă $G$, Hăncianu $\mathrm{M}$, In vitro antioxidant activity of some extracts obtained from Agaricus bisporus brown, Pleurotus ostreatus and Fomes fomentarius. Farmacia, 2015; 63(6): 927-933.

26. Moisa C, Copolovici L, Bungău S, Pop G, Imbrea I, Lupitu A, Nemeth S, Copolovici D, Wastes resulting from aromatic plants distillation - Bio-sources of antioxidants and phenolic compounds with biological active principles. Farmacia, 2018; 66(2): 289-295.
27. Nowacka N, Nowak R, Drozd M, Olech M, Los R, Malm A, Antibacterial, antiradical potential and phenolic compounds of thirty-one polish mushrooms. Plos One, 2015, 10(10): 1-13.

28. Obodai M, Ferreira ICFR, Fernandes A, Barros L, Narh Mensah DL, Dzomeku M, Urben AF, Prempeh J, Takli RK, Evaluation of the chemical and antioxidant properties of wild and cultivated mushrooms of Ghana. Molecules, 2014; 19: 19532-19548.

29. Popovici V, Bucur L, Popescu A, Caraiane A, Badea $\mathrm{V}$, Determination of the content in usnic acid and polyphenols from the extracts of Usnea barbata $\mathrm{L}$. and the evaluation of their antioxidant activity. Farmacia, 2018; 66(2): 337-341.

30. Quang DN, Hashimoto T, Asakawa Y, Inedible mushrooms: A good source of biologically active substances. Chem Record, 2006; 6: 79-99.

31. Ramadan A, Soliman G, Mahmoud SS, Nofal SM, Abdel-Rahman RF, Evaluation of the safety and antioxidant activities of Crocus sativus and Propolis ethanolic extracts. J Saudi Chem Soc., 2012; 16: 13-21.

32. Reis FS, Pereira E, Barros L, Sousa MJ, Martins A, Ferreira IC, Biomolecule profiles in inedible wild mushrooms with antioxidant value. Molecules, 2011; 16(6): 4328-4338.

33. Reis FS, Martins A, Barros L, Ferreira ICFR, Antioxidant properties and phenolics profile of the most widely appreciated cultivated mushrooms: A comparative between in vivo and in vitro samples. Food Chem Toxicol., 2012; 50: 1201-1207.

34. Robles-Hernandez L, Cecilia-Gonzalez-Franco A, Soto-Parra JM, Montes-Dominguez F, Review of agricultural and medicinal applications of basidiomycete mushrooms. Tecnociencia Chihuahua, 2008; 2(2): 95-107.

35. Robbins RJ, Bean SR, Development of a quantitative high-performance liquid chromatography-photodiode array detection measurement system for phenolic acids. J Chromatogr A, 2004; 1038(1-2): 97-105.

36. Satyanarayana U, Chakrapani U, Biochemistry, $4^{\text {th }}$ ed., Ed. Elsevier, India, 2013, 655-660.

37. Seniuk OF, Gorovoj LF, Beketova GV, Savichuk NO, Rytik PG, Kucherov II, Prilutskaya AB, Prilutsky AI, Anti-infective properties of the melanin-glucan complex obtained from medicinal tinder bracket mushroom, Fomes fomentarius (L.: Fr.) Fr. (Aphyllophoromycetideae). Int J Med Mushrooms, 2011; 13(1): 7-18.

38. Vazirian M, Dianat S, Manayi A, Ziari R, Mousazadeh A, Habibi E, Saeidnia S, Amanzadeh Y, Antiinflammatory effect, total polysaccharide, total phenolics content and antioxidant activity of the aqueous extract of three basidiomycetes. Res J Pharmacogn., 2014; 1: $15-21$.

39. Yang CW, Mousa SA, The effect of red yeast rice (Monascus purpureus) in dyslipidemia and other disorders. Complement Ther Med., 2012; 20(6): 466-474.

40. Wang ZB, Pei JJ, Ma HL, Cai PF, Yan JK, Effect of extraction media on preliminary characterizations and antioxidant activities of Phellinus linteus polysaccharides. Carbohydr Polym., 2014; 109: 49-55. 